\title{
Reduced tillage and nitrogen effects on soil water dynamics and maize (Zea mays L.) yield under semi-arid conditions
}

\section{Walter Mupangwa, Steve Twomlow \& S. Walker}

To cite this article: Walter Mupangwa, Steve Twomlow \& S. Walker (2016) Reduced tillage and nitrogen effects on soil water dynamics and maize (Zea mays L.) yield under semiarid conditions, International Journal of Agricultural Sustainability, 14:1, 13-30, DOI: $\underline{10.1080 / 14735903.2015 .1011393}$

To link to this article: http://dx.doi.org/10.1080/14735903.2015.1011393

Published online: 19 Feb 2015.

Submit your article to this journal $\square$

Џ Article views: 97

View related articles

View Crossmark data $\asymp$ 


\title{
Reduced tillage and nitrogen effects on soil water dynamics and maize (Zea mays L.) yield under semi-arid conditions
}

\author{
Walter Mupangwa ${ }^{\mathrm{a}, \mathrm{b}, \mathrm{c} *}$, Steve Twomlow ${ }^{\mathrm{d}}$ and S. Walker ${ }^{\mathrm{b}}$ \\ ${ }^{a}$ ICRISAT, Matopos Research Station, P.O. Box 776, Bulawayo, Zimbabwe; ${ }^{b}$ Department of Soil, Crop \\ and Climate Sciences, University of Free State, P.O. Box 339, Bloemfontein 9300, South Africa; \\ ${ }^{c}$ CIMMYT, Southern Africa Regional Office, P.O. Box MP 163, Harare, Zimbabwe; ${ }^{d}$ IFAD Eastern and \\ Southern Africa Regional Office, Nairobi, Kenya
}

\begin{abstract}
Soil water and nutrients are critical drivers of crop production for smallholders of southern Africa. A three-year study was conducted to assess the effect of integrating single and double ploughing, ripping and planting basins with nitrogen fertilizer $\left(0,10\right.$ and $\left.20 \mathrm{~kg} \mathrm{~N}^{-1}\right)$ on soil water dynamics and maize (Zea mays L.) yields. The experimental design was factorial with four tillage methods and three nitrogen levels as treatment factors. The study was conducted under semi-arid conditions of Zimbabwe. Tillage methods had similar soil water patterns in the profile and no tillage $\times \mathrm{N}$ interaction effects were observed on soil water dynamics. Soil water penetrated deeper into the profile under ripper and basin methods than conventionally ploughed treatments. Nitrogen increased maize yields (14-96\%) and rainwater-use efficiency (20-92\%) regardless of tillage methods and growing season quality. However, more studies are required to explore complementary techniques that can improve rainwater capture and prolong soil water storage, and improve soil fertility.
\end{abstract}

Keywords: basins; conventional ploughing; rainwater-use efficiency; soil fertility; tine ripping

\section{Introduction}

Soil water and nutrients are critical drivers of crop production in smallholder farming systems of sub-Saharan Africa (Mapfumo \& Giller, 2001; Twomlow, Steyn, \& du Preez, 2006). In semi-arid smallholder farming systems, the availability of adequate soil water for crop production is often limited by the low and variable in-season rainfall (Cooper et al., 2008; Graef \& Haigis, 2001), low water holding capacity of highly degraded soils (Twomlow et al., 2006) and non-transpiration field water fluxes that do not benefit the growing crop (Mupangwa \& Jewitt, 2011). In southern Africa, as in other regions with rainfed smallholder agriculture, crop production is further constrained by low soil fertility with nitrogen $(\mathrm{N})$ and phosphorus as the major limiting plant nutrients (Cobo, Dercon, \& Cadisch, 2010; Kolawole, 2013). To cope with soil water stress and low crop productivity in semi-arid environments, smallholder farmers ought to adopt a combination of soil water and fertility management strategies that have been developed and refined through research.

Traditionally, tillage has been adopted as an option for managing rainwater in semi-arid agroecosystems (Debaeke \& Aboudrare, 2004; Twomlow \& Bruneau, 2000). Soil surface roughness created by tillage plays a critical role in rainfall storage in surface depressions, infiltration of rainwater into the soil and reducing surface run-off from cropping fields (Alvarez-Mozos, Angel Campo, Gimenez, Casali, \& Leibar, 2011; Guzha, 2004; Mupangwa, Twomlow, \& Walker, 2008). In situ rainwater-harvesting techniques, such as clean and mulch ripping (Nyagumbo,

*Corresponding author. Emails: mupangwa@yahoo.com; w.mupangwa@cgiar.org 
2002; Mupangwa, Twomlow, \& Walker, 2012a), pot-holing between crop rows, tied-ridging and tied-furrowing (Nyakatawa, Brown, \& Maringa, 1996; Twomlow \& Bruneau, 2000; Vogel, 1992), and hand-dug planting basins of various dimensions (Mupangwa et al., 2008; Twomlow, Urolov, Oldrieve, \& Jenrich, 2008), have been explored in southern Africa. Post-harvest winter ploughing is a recommended practice for semi-arid environments (Mupangwa, Love, \& Twomlow, 2006) but is rarely practiced by smallholders despite the well-documented advantages it has on some soil types (Dryland Farming Research Scheme [DLFRS], 1985; Grant, Meikle, \& Mills, 1979). Double conventional ploughing, with the first ploughing operation carried out just before the onset of the rains, showed a significant influence on soil water storage and subsequent crop yields in studies conducted in southern Africa (DLFRS, 1985; Twomlow \& Bruneau, 2000).

In cropping seasons with favourable rainfall and soil moisture conditions, crop yields are often limited by poor soil fertility (Ncube, Dimes, van Wijk, Twomlow, \& Giller, 2009). Inappropriate soil-fertility management is one of the several reasons for declining household food production in southern Africa (Ncube, Twomlow, van Wijk, Dimes, \& Giller, 2007). Low usage of improved soil-fertility management technologies can be attributed to high inorganic fertilizer prices, blanket fertilizer recommendations developed without taking rainfall risk into consideration and fertilizer recommendations that do not match the socio-economic circumstances of farmers (Dimes, Muza, Malunga, \& Snapp, 2004). Studies conducted in south-western Zimbabwe indicated that cereal yields increased substantially by using livestock manure and inorganic fertilizers (Ncube, Dimes, Twomlow, Mupangwa, \& Giller, 2007; Twomlow et al., 2008). Appropriate soil-fertility management practices through the use of livestock manure and inorganic fertilizers can enhance rainwater-use efficiency (RWUE) and subsequently increase crop yields in smallholder systems (De Barros, Gaiser, Lange, \& Romheld, 2007).

The hand-dug planting basins and animal-drawn ripper tillage methods were selected for the study because they were being promoted under conservation agriculture programmes in smallholder agro-ecosystems of southern Africa (Twomlow, Urolov, et al., 2008). Double conventional ploughing was included in the study based on the positive results obtained in previous studies under semi-arid conditions of southern Africa (DLFRS, 1985; Twomlow \& Bruneau, 2000). Maize was selected as the test crop because it is the dominant cereal grown by smallholders in south-western Zimbabwe. Previous studies in south-western Zimbabwe focussed on soil-fertility management practices (Ncube, Dimes, et al., 2007, Ncube, Twomlow, et al., 2007; Ncube et al., 2009; Twomlow, Rohrbach, et al., 2008), while others explored the effect of rainwater-harvesting techniques on soil water retention under smallholder conditions (Motsi, Chuma, \& Mukamuri, 2004; Mugabe, 2004; Mupangwa, Twomlow, \& Walker, 2012b). In the reported study, we hypothesized that combining soil water management through available tillage methods and application of inorganic $\mathrm{N}$ fertilizer improves soil water availability, and increases maize yields and RWUE in semi-arid smallholder agro-ecosystems of southern Zimbabwe. The study objectives were (1) to assess soil water patterns under single and double conventional ploughing, tine ripping and planting basin tillage methods and (2) to determine the effect of the four tillage methods and $\mathrm{N}$ fertilizer on maize yield and RWUE. Maize was used in the study because it is one of the dominant cereals grown by smallholders in south-western Zimbabwe (Mupangwa, et al., 2012a; Twomlow, Rohrbach, et al., 2008).

\section{Materials and methods}

\section{Description of experimental sites}

Insiza and Gwanda districts lie in the Mzingwane catchment, which is part of the Limpopo river basin. Insiza district lies in the Agro-ecological region (NR) 4, which is characterized by semi-arid 
Table 1. Selected initial soil chemical and physical properties $(0-0.6 \mathrm{~m})$ at experimental farms used from 2005/2006 to 2007/2008 in Insiza and Gwanda districts (adapted from Mupangwa, 2009).

\begin{tabular}{|c|c|c|c|c|c|c|}
\hline District & Farmer & $\begin{array}{c}\mathrm{pH} \\
\text { (water) }\end{array}$ & $\begin{array}{l}\text { Organic carbon } \\
\quad\left(\mathrm{mg} \mathrm{kg}^{-1}\right)\end{array}$ & $\begin{array}{c}\text { Total N } \\
\left(\mathrm{mg} \mathrm{kg}^{-1}\right)\end{array}$ & $\begin{array}{c}\text { Total P } \\
\left(\mathrm{mg} \mathrm{kg}^{-1}\right)\end{array}$ & $\begin{array}{l}\text { B. density } \\
\left(\mathrm{g} \mathrm{cm}^{-\mathbf{3}}\right)\end{array}$ \\
\hline \multirow[t]{7}{*}{ Insiza } & Mguni & 6.0 & 5.6 & 0.5 & 0.20 & 1.50 \\
\hline & Мoyo & 5.9 & 5.8 & 0.6 & 0.06 & 1.49 \\
\hline & Mpofu & 5.2 & 4.1 & 0.3 & 0.07 & 1.46 \\
\hline & Nkomo & 5.6 & 3.6 & 0.2 & 0.06 & 1.50 \\
\hline & Mlalazi & 5.5 & 3.6 & 0.2 & 0.09 & 1.52 \\
\hline & Ncube N & 6.5 & 3.4 & 0.2 & 0.02 & 1.52 \\
\hline & Nyathi & 6.3 & 2.9 & 0.3 & 0.08 & 1.51 \\
\hline \multirow[t]{5}{*}{ Gwanda } & Ncube $\mathrm{J}$ & 5.3 & 3.3 & 0.3 & 0.09 & 1.49 \\
\hline & Sibanda & 5.6 & 4.6 & 0.3 & 0.21 & 1.51 \\
\hline & Siziba & 6.1 & 7.1 & 0.6 & 0.19 & 1.56 \\
\hline & $\operatorname{LSD}_{0.05}$ & 0.53 & 1.8 & 0.33 & 0.07 & 0.020 \\
\hline & CV (\%) & 7.3 & 29 & 40 & 43 & 1.1 \\
\hline
\end{tabular}

climatic conditions with total annual rainfall ranging between 450 and $600 \mathrm{~mm}$ (FAO, 2006). Gwanda district lies in NR 5, which receives annual rainfall of less than $450 \mathrm{~mm}$. Evaporation varies from $1600 \mathrm{~mm}_{\text {year }}{ }^{-1}$ to more than $2600 \mathrm{~mm}_{\text {year }}{ }^{-1}$ and it is high even during the rainfall season (FAO, 2004). Daily evaporative losses of 5-8 $\mathrm{mm}^{\text {day }}{ }^{-1}$ have been recorded in some parts of the Limpopo Basin (Woltering, 2005). Daily summer temperature may exceed $40^{\circ} \mathrm{C}$, while winter temperatures can go below $0^{\circ} \mathrm{C}$. In both districts, the rainfall season is unimodal and begins in November/December and ends in March/April. The cropping season experiences periodic dry spells, particularly in January, and is followed by a cool to warm dry season from May to September (Mupangwa, Walker, \& Twomlow, 2011). Soil properties of experimental sites are summarized in Table 1. The predominant soils in Insiza and Gwanda districts are coarse-grained sands to loamy sands and clay loams to clay with minor occurrences of vertisols (Anderson, Brinn, Moyo, \& Nyamwanza, 1993). The soils are classified as 2, 4P and 5G (Zimbabwe Soil Classification), Eutric/Dystric Regosols and Chromic Luvisols (FAO/UNESCO classification) and as Ustalfic Haplargid and Lithic/Ustic Torriorthent (Soil Taxonomy) (FAO, 2006; Nyamapfene, 1991).

\section{Experimental design and management}

The experimental design was laid out in a randomized complete block design with treatments arranged in a factorial structure. Each farm was used as a replicate and a total of 5 farms were used in the 2005/2006 season, 7 farms in the 2006/2007 season and 11 farms in the 2007/2008 season. However, crop-yield data were collected from only 4 farms in the 2006/2007 season because of the drought experienced in that season. The four tillage methods were planting basins (Basins), tine ripping (Ripper), single (CP) and double (DP) conventional ploughing. The three $\mathrm{N}$ rates were 0,10 and $20 \mathrm{~kg} \mathrm{~N} \mathrm{ha}^{-1}$ applied as ammonium nitrate $(34.5 \% \mathrm{~N})$ in a single dose at 5-6 weeks after planting. The $\mathrm{N}$ rates were selected based on results from earlier studies done by Ncube, Dimes, et al. (2007) and Twomlow, Rohrbach, et al. (2008). Each tillage main plot measured $20 \mathrm{~m} \times 10 \mathrm{~m}$ in the 2005/2006 season and was increased to $30 \mathrm{~m} \times 10 \mathrm{~m}$ in $2006 / 2007$ and $2007 / 2008$ seasons. In the first season (2005/2006), only 0 and $10 \mathrm{~kg} \mathrm{~N}^{-1}$ were used while a third rate of $20 \mathrm{~kg} \mathrm{~N}$ ha $^{-1}$ was introduced in 2006/2007 and the three $\mathrm{N}$ application rates were maintained in the $2007 / 2008$ growing season. 
In the 2005/2006 season, plots were pegged out in October 2005 before all tillage operations commenced. In the 2006/2007 season, new plots were pegged out in adjacent fields because main plot size had increased from $20 \mathrm{~m} \times 10 \mathrm{~m}$ to $30 \mathrm{~m} \times 10 \mathrm{~m}$ to accommodate the third $\mathrm{N}$ subplot under each tillage method. The plots established in the 2006/2007 season were maintained for 2007/2008 growing season. Planting basins were dug at $0.9 \mathrm{~m} \times 0.6 \mathrm{~m}$ spacing using a hand hoe and each basin measured $0.15 \mathrm{~m}$ (length) $\times 0.15 \mathrm{~m}$ (width) $\times 0.15 \mathrm{~m}$ (depth) based on recommendations from earlier studies (Twomlow, Urolov, et al. 2008). Rip lines were opened at $0.9 \mathrm{~m}$ inter-row spacing using a ZimPlow ripper tine attached to the beam of an ox/donkey-drawn mouldboard plough (VS 100). The ripping depth achieved with a single pass of the ripper tine varied between 0.15 and $0.18 \mathrm{~m}$, depending on antecedent soil moisture conditions.

Digging of basins and ripping were done before the onset of the rains as recommended for drier regions (Twomlow, Hove, Mupangwa, Masikati, \& Mashingaidze, 2009; Twomlow, Urolov, et al., 2008). The planting basin and ripper tillage systems were designed for maize with a target population of 37,000 plants per hectare under semi-arid conditions (Twomlow, Urolov, et al., 2008). The first conventional ploughing for the DP treatment was carried out in October each year. The second ploughing was done at the same time as the CP treatment soon after the first effective rain $(20-30 \mathrm{~mm})$ in November/December each year using a donkeydrawn mouldboard plough (VS 100) as practiced by smallholders in south-western Zimbabwe. In the CP and DP treatments, planting furrows were opened at $0.9 \mathrm{~m}$ and the ploughing depth achieved varied between 0.15 and $0.2 \mathrm{~m}$.

Cattle manure (averaging $40 \% \mathrm{C}, 0.43 \% \mathrm{~N}$ and $0.21 \% \mathrm{P}$ ) was applied each year at a rate of $3 \mathrm{tha}^{-1}$ in all plots as basal soil-fertility amendment. In the ripper and basin tillage treatments, manure was dribbled along the ripline and placed in the planting basins. In the CP and DP treatments, manure was broadcast just before the ploughing operation as it is normally done by smallholders in Zimbabwe. The annual $3 \mathrm{t} \mathrm{ha}^{-1}$ application rate for manure was based on the results from Ncube, Dimes, et al. (2007) for smallholders in a semi-arid environment. Planting on all farms occurred between late November and early December each year depending on the start of the rainy season. A short duration ( $\sim 120$ days) commercial maize hybrid SC 403 was planted at all farms during each of the three cropping seasons. Three kernels were planted per basin in the basin tillage system. Two kernels were planted per station at $0.3 \mathrm{~m}$ in-row spacing in the ripping, single and double conventional tillage treatments. Plants were thinned to two per basin in planting basin treatment and one plant per station in the ripping, single and double conventional ploughing treatments two weeks after planting. Ammonium nitrate $(34.5 \% \mathrm{~N})$ was spot applied at the base of maize plants at 10 and $20 \mathrm{~kg} \mathrm{~N}^{-1}$ as topdressing at 5-6 weeks after planting. The $\mathrm{N}$ rate was selected based on results from earlier studies done by Ncube, Dimes, et al. (2007), Ncube, Twomlow, et al. (2007) and Twomlow, Rohrbach, et al. (2008) in south-western Zimbabwe. During each growing season, weeds were controlled manually as required using a hand hoe in all treatments and during the dry season, plots were kept weed-free by hand weeding when necessary.

\section{Data collection}

\section{Soil water measurements}

In 2005/2006 and 2006/2007 seasons, soil water was measured from two farms in Insiza and three farms in Gwanda districts. In the 2007/2008 season, soil water was measured from three farms in Insiza and three farms in Gwanda districts. Soil water content was measured using the gravimetric method during the 2005/2006 season. Three sampling positions in each main plot (i.e. tillage 
method) were used at each farm and soils were dried at $105^{\circ} \mathrm{C}$ for $48 \mathrm{~h}$ as described by Anderson and Ingram (1997). Soil water content was then calculated using the soil bulk density based on the procedure given by Anderson and Ingram (1997). In 2006/2007 and 2007/2008 seasons, volumetric soil water content was measured using a capacitance probe (microgopher sensor type). The depth of access tubes averaged $0.6 \mathrm{~m}$ and one access tube was installed per subplot under the main plot tillage method at each farm. Soil water was measured at $0.1 \mathrm{~m}$ depth increments after planting and before harvesting the maize crop in all seasons. In 2006/2007 and 2007/ 2008 seasons, soil water content in millimetres was determined by multiplying volumetric water content by thickness of each layer from which soil water was measured following the procedure outlined by Anderson and Ingram (1997). Each farmer was given a manual plastic rain gauge for recording daily rainfall during each growing season.

\section{Maize yield}

At harvest, maize grain and above-ground biomass yields were measured from the $10 \mathrm{~m} \times$ $10 \mathrm{~m}$ subplot of each tillage treatment. The weight of cobs and stover from the subplot of each tillage treatment was determined in the field before taking sub-samples for moisture correction. Grain and stover samples were dried at $60^{\circ} \mathrm{C}$ for $48 \mathrm{~h}$ for moisture adjustment. The maize shelling percentage was determined for each treatment for converting ear weight into grain weight. Grain weight was converted to a per hectare basis at $12.5 \%$ moisture content as a final grain yield.

\section{Rainwater-use efficiency}

RWUE was computed using the total rainfall received between sowing and harvesting of maize, and the grain yield achieved from the treatments at each experimental farm each season. Equation (1) summarizes the computation of RWUE:

$$
\operatorname{RWUE}\left(\mathrm{kg} \mathrm{ha}^{-1} \mathrm{~mm}^{-1}\right)=\frac{\operatorname{Grain} \text { yield }\left(\mathrm{kg} \mathrm{ha}^{-1}\right)}{\text { total rainfall }(\mathrm{mm})} .
$$

\section{Statistical analyses of soil water content, maize yield and $R W U E$}

Soil water, maize yield and RWUE data were analysed using analysis of variance (ANOVA) in Statistix 9.0 (Statistix, 2008). Soil water content in the $0-0.50 \mathrm{~m}$ profile was analysed using the factorial treatment structure in ANOVA with tillage method, date of soil water measurement and soil depth as the treatment variables. Maize yield and RWUE data were also analysed using the factorial treatment structure in ANOVA with tillage method and N fertilizer as treatment variables. Soil water, maize yield and RWUE data were analysed for the three seasons separately in order to get a clear assessment of the influence of treatment variables on soil water dynamics, maize yield and RWUE under different rainfall patterns which were experienced in south-western Zimbabwe during the period of experimentation. When the $F$-test indicated significant treatment mean differences, the least significant difference (LSD) at 5\% was used to compare the means. In 2006/2007 and 2007/2008 seasons, the relationship between maize grain yield and $\mathrm{N}$ fertilizer rates was assessed using regression models in Statistix 9.0 (Statistix, 2008). 


\section{Results}

\section{Seasonal rainfall and soil water distribution}

\section{5/2006 season}

Insiza district (NR 4) received more and well-distributed daily rainfall compared with Gwanda during the 2005/2006 growing season (Figure 1). Total seasonal rainfall ranged from 535 to $541 \mathrm{~mm}$ in Insiza and from 271 to $431 \mathrm{~mm}$ in Gwanda. The majority of rainfall amounts received in Insiza was more than $10 \mathrm{~mm}$ per day, while in Gwanda most of the rain fell in showers of less than $10 \mathrm{~mm}$ per day. Insiza received 24 rainfall events of $>10 \mathrm{~mm} /$ day, while Gwanda recorded only 9 events during the cropping period. The longest dry spell lasted 9 days in Insiza district (NR 4 ) and 13 days in Gwanda (NR 5).

In the 2005/2006 season, soil depth $\times$ date of measurement interaction influenced $(P=$ 0.006 ) water content measured in the $0-0.50 \mathrm{~m}$ profile regardless of the tillage method used in Gwanda district (Figure 2). Soil water patterns in the four tillage methods varied in response to rainfall events during the cropping period (Figure 2). In Insiza, tillage method, date and depth of water measurement had a significant effect on soil water patterns. In Insiza, water had penetrated deeper into the soil profile of ripper treatment at the beginning of the season compared with the other tillage methods (Figure 3). During mid-season (e.g. 13 February 2006), soil water had penetrated into deeper soil layers in the basin treatment compared with the other tillage methods (Figure 3). At the end of the 2005/2006 cropping season, basins had more water at soil depths $>20 \mathrm{~cm}$ compared to the other tillage methods. In the conventionally ploughed treatments, CP had more water in the $0-10 \mathrm{~cm}$ soil layer while the DP method was wetter in the $20-30 \mathrm{~cm}$ layer in the middle of the cropping season (illustrated by 22 February 2006). Soil profiles in Gwanda had less water compared to Insiza across the four tillage methods tested (Figures 2 and 3).

\section{6/2007 season}

Rainfall was poorly distributed at all experimental farms in the 2006/2007 season (Figure 4). Total seasonal rainfall ranged from 297 to $456 \mathrm{~mm}$ in Insiza and 238 to $317 \mathrm{~mm}$ in Gwanda district. Insiza and Gwanda received 19 and 9 rainfall events of $>10 \mathrm{~mm} \mathrm{day}^{-1}$ respectively, during the 2006/ 2007 season. A 42-day dry spell was recorded during the January-February 2007 period in Insiza district, while the longest dry spell lasted 55 days in Gwanda. The tillage method, date and depth of measurement influenced soil water in Gwanda. The ripper tillage method had the higher soil water content in the profile regardless of the date of measurement compared with the
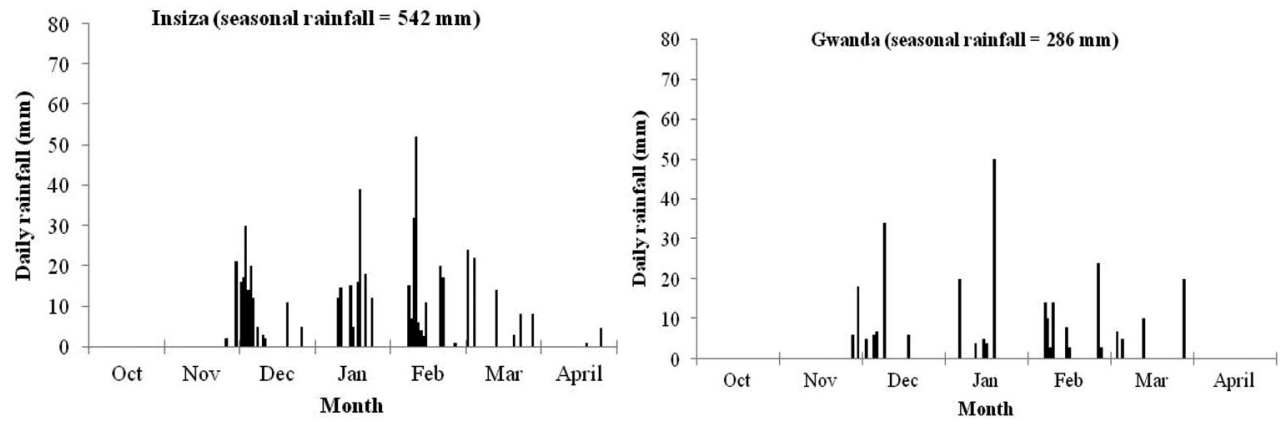

Figure 1. Daily rainfall recorded at some of the experimental sites in Insiza (NR 4) and Gwanda (NR 5) districts during the 2005/2006 cropping season. 

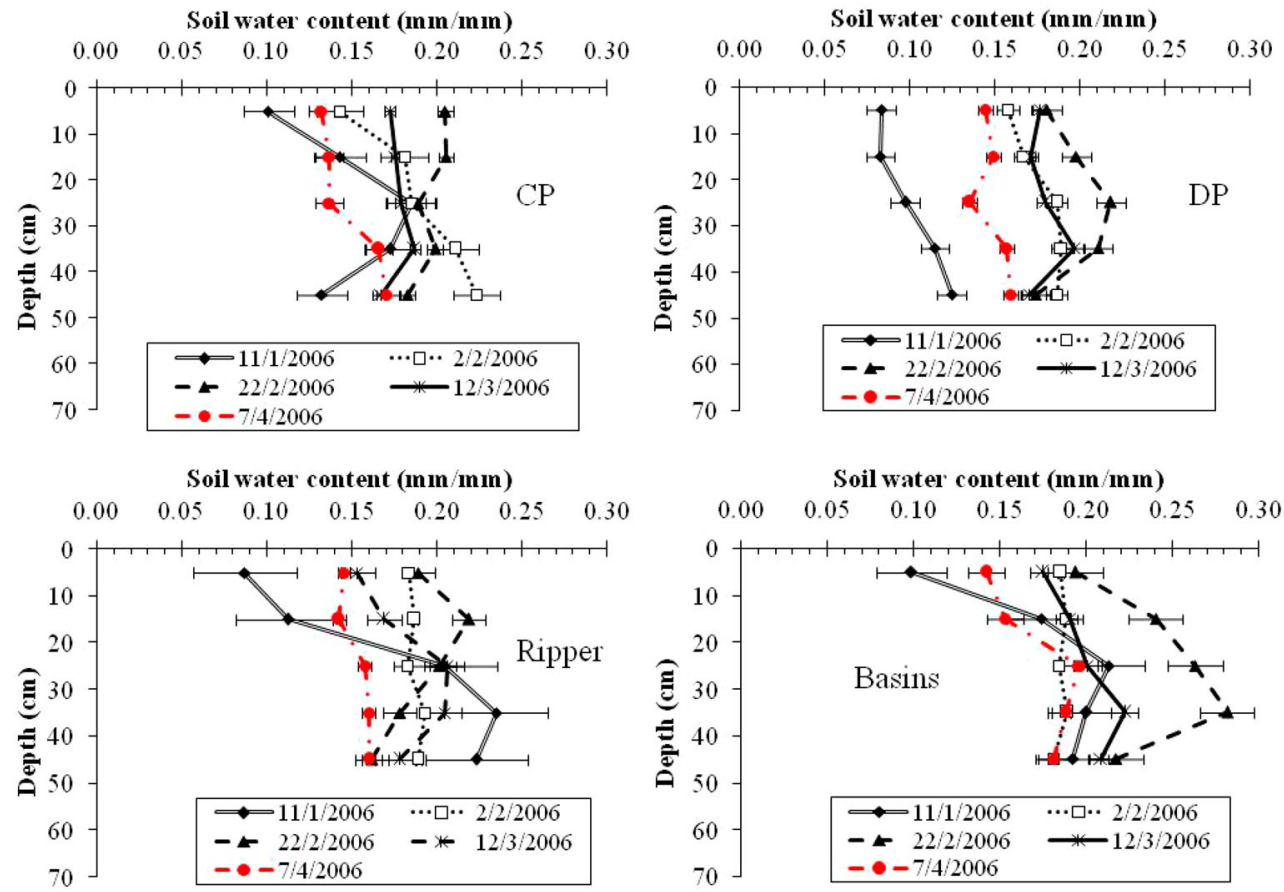

Figure 2. Soil water distribution patterns with soil depth in four tillage methods tested in Gwanda district (NR 5) during the 2005/2006 season. Horizontal bars represent standard error $(n=9)$.

other tillage methods (Figure 5). When averaged across tillage methods and water measurement dates, the $0-15 \mathrm{~cm}$ layer had the lowest soil water content. In Insiza, the tillage method and date of measurement significantly influenced soil water and basins had a higher water content compared with the other tillage methods. As observed in Gwanda, soil profile had more water in the first half of the season compared with the February-March period (Figure 6). Soil water content was also high in April following rainfall received in that month.

\section{$2007 / 2008$ season}

Total seasonal rainfall ranged from 288 to $541 \mathrm{~mm}$ in Insiza and from 222 to $303 \mathrm{~mm}$ in Gwanda. The growing season was characterized by early cessation of rains in both agro-ecological zones (Figure 7), with 14 and 5 rainfall events of $>10 \mathrm{~mm} \mathrm{day}^{-1}$ for Insiza and Gwanda, respectively. Major rainfall events ended in January 2008 in both districts, with Insiza receiving only $5 \mathrm{~mm}$ on 17 March 2008 and $3 \mathrm{~mm}$ was recorded on 28 February 2008 in Gwanda.

In Gwanda and Insiza, soil depth $\times$ date of water measurement interaction influenced $(P<$ $0.001)$ water content recorded in all tillage treatments. Tillage method $\times$ date of measurement interaction affected $(P=0.026)$ soil water patterns in Gwanda. The wetting cycle was evident at the beginning of season and the $0-20 \mathrm{~cm}$ soil layer under different tillage treatments was the driest during February 2008 (Figure 8). Soil water penetrated the profile faster in the ripper treatment following heavy rain received during early January 2008 compared with the other treatments. From February to April soil profiles under the four tillage methods showed similar drying patterns although ripper dried faster than the other treatments (Figure 8). At beginning of 2007/ 2008 season in Insiza, rainwater capturing, reflected by high soil water content in the top layer, was similar in the DP, basins and ripper treatments with basins having the highest water 


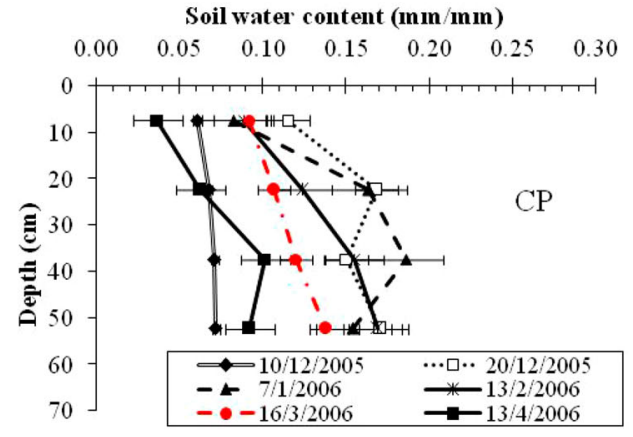

Soil water content ( $\mathrm{mm} / \mathrm{mm})$

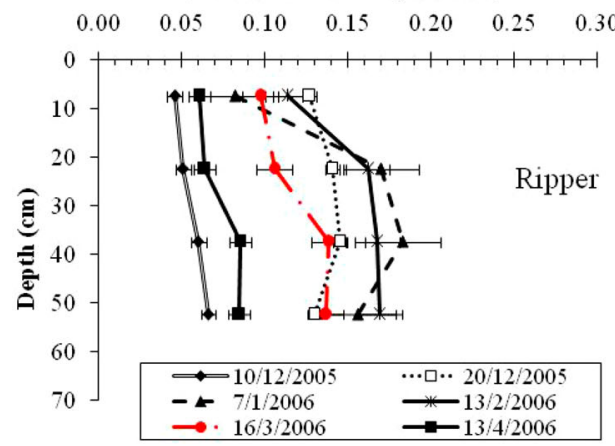

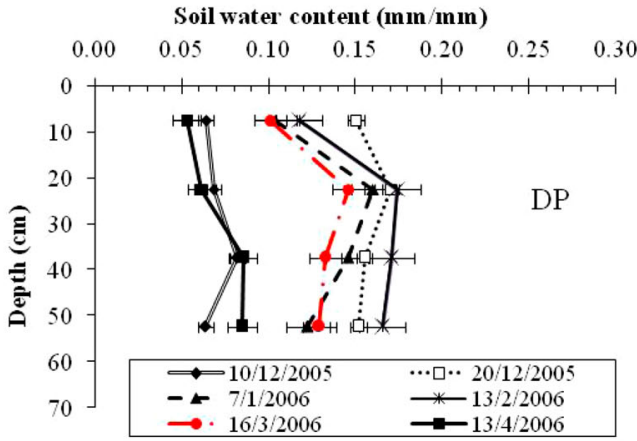

Soil water content (min/min)

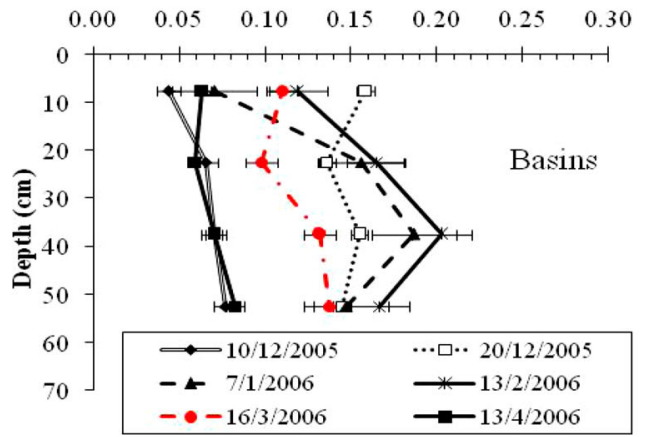

Figure 3. Soil water distribution patterns with soil depth in four tillage methods tested in Insiza district (NR 4) during the $2005 / 2006$ season. Horizontal bars represent standard error $(n=6)$.
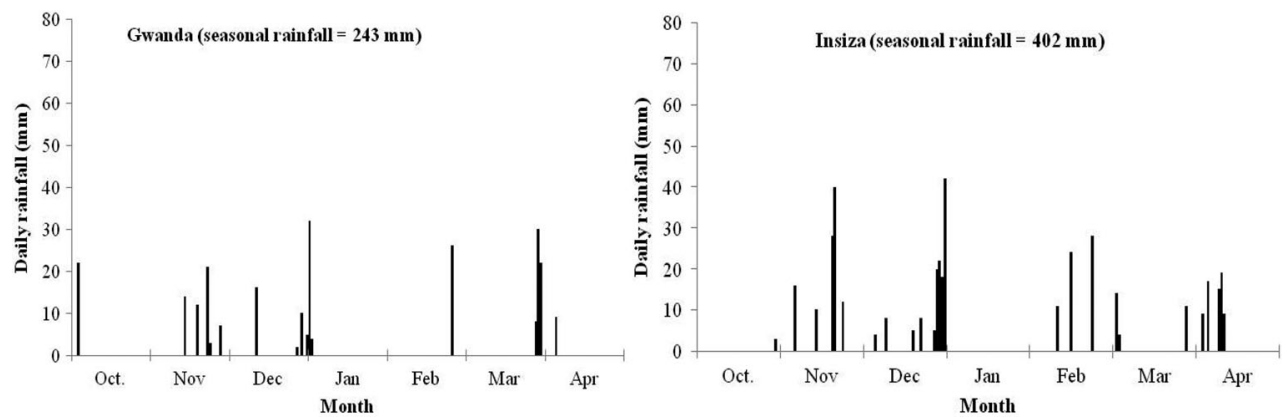

Figure 4. Daily rainfall recorded at some of the experimental sites in Insiza (NR 4) and Gwanda (NR 5) districts during the 2006/2007 cropping season.

content in the $0-10 \mathrm{~cm}$ layer (Figure 9). As the season progressed from December 2007 to April 2008 , the $0-20 \mathrm{~cm}$ layer dried faster in the CP and ripper treatments, while basins retained more water in the same layer during the same period (Figure 9).

\section{Effect of tillage methods and nitrogen fertilizer on grain yield and $R W U E$}

Maize grain yield was not influenced $(P=0.71)$ by the tillage method across all experimental farms in the $2005 / 2006$ season. Nitrogen increased grain yield $(P=0.049)$ and RWUE $(P=0.0015)$ (Tables 2 and 3). The tillage method and $\mathrm{N}$ fertilizer interaction had no 

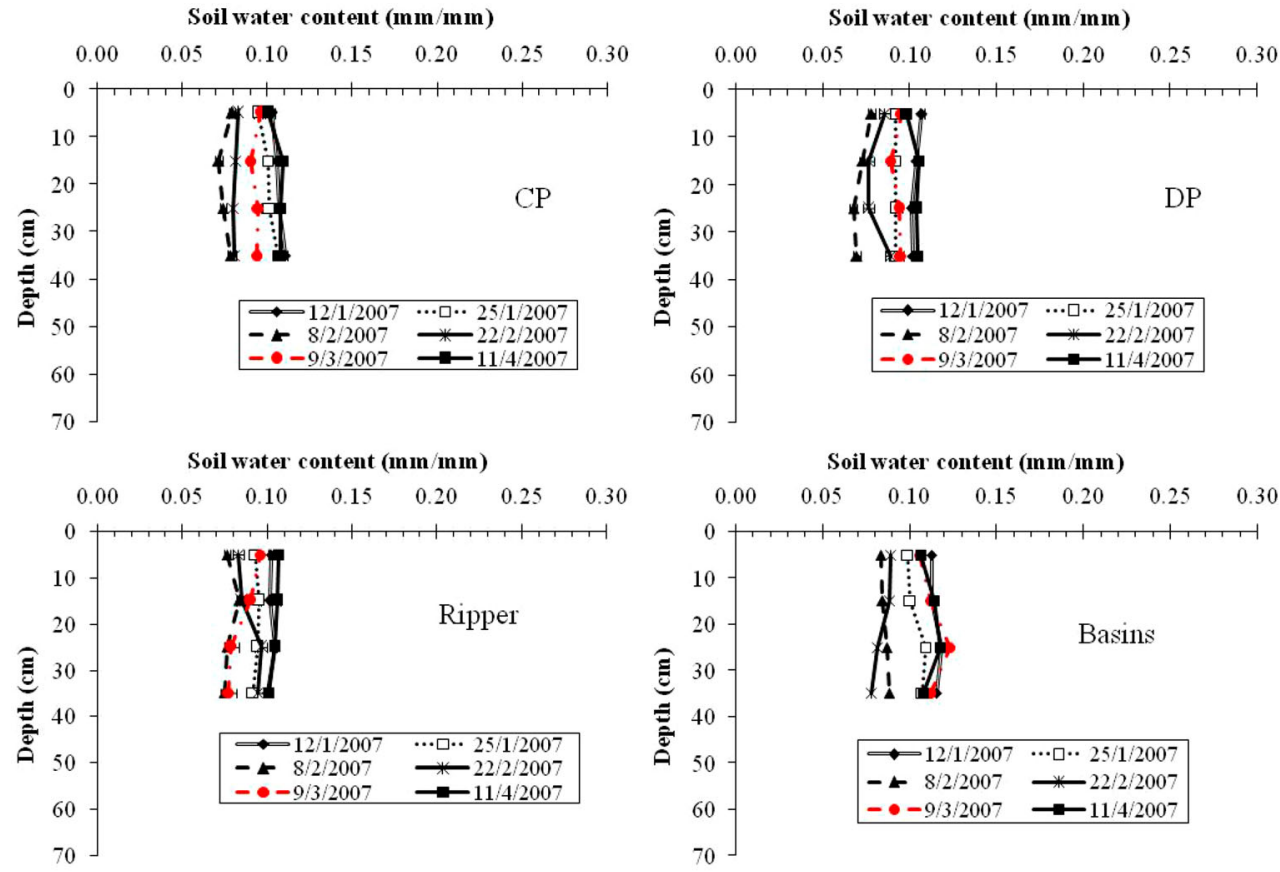

Figure 5. Soil water distribution patterns with soil depth in four tillage methods tested in Gwanda district (NR 5) during the 2006/2007 season. Horizontal bars represent standard error $(n=9)$.

significant $(P>0.05)$ influence on grain yield and RWUE in 2005/2006 and 2006/2007 seasons. However, $\mathrm{N}$ also increased grain yield $(P=0.0226)$ and RWUE $(P=0.0016)$ in the $2006 / 2007$ season. In the 2006/2007 season, the relationship between grain yield and $\mathrm{N}$ fertilizer quantities applied was linear $\left(P=0.023 ; r^{2}=0.21\right)$ and can be described by:

$$
\text { Grain yield }\left(\mathrm{kg} \mathrm{ha}^{-1}\right)=279.9+13.6 \mathrm{~N}
$$

where $\mathrm{N}$ is the amount of nitrogen applied in $\mathrm{kg} \mathrm{ha}^{-1}$.

In the $2007 / 2008$ season, the tillage method and tillage $\times \mathrm{N}$ interaction had no significant $(P$ $>0.05)$ effect on grain yield and RWUE. However, grain yield $(P=0.005)$ and RWUE $(P<$ 0.001 ) increased with an increase in $\mathrm{N}$ applied, regardless of the tillage method used (Table 4). A quadratic relationship existed between maize grain yield and $\mathrm{N}$ quantities applied in the 2007/2008 season $\left(P<0.033 ; r^{2}=0.45\right)$ and can be summarized by:

$$
\text { Grain yield }\left(\mathrm{kg} \mathrm{ha}^{-1}\right)=839+20.4 \mathrm{~N}-0.32 \mathrm{~N}^{2}
$$

where $\mathrm{N}$ is the amount of nitrogen applied in $\mathrm{kg} \mathrm{ha}^{-1}$.

\section{Discussion}

\section{Seasonal rainfall patterns}

The 2005/2006 season recorded above average and well-distributed rainfall in Insiza and Gwanda, and was adequate to meet the $500 \mathrm{~mm}$ in-crop rainfall requirement for most maize 

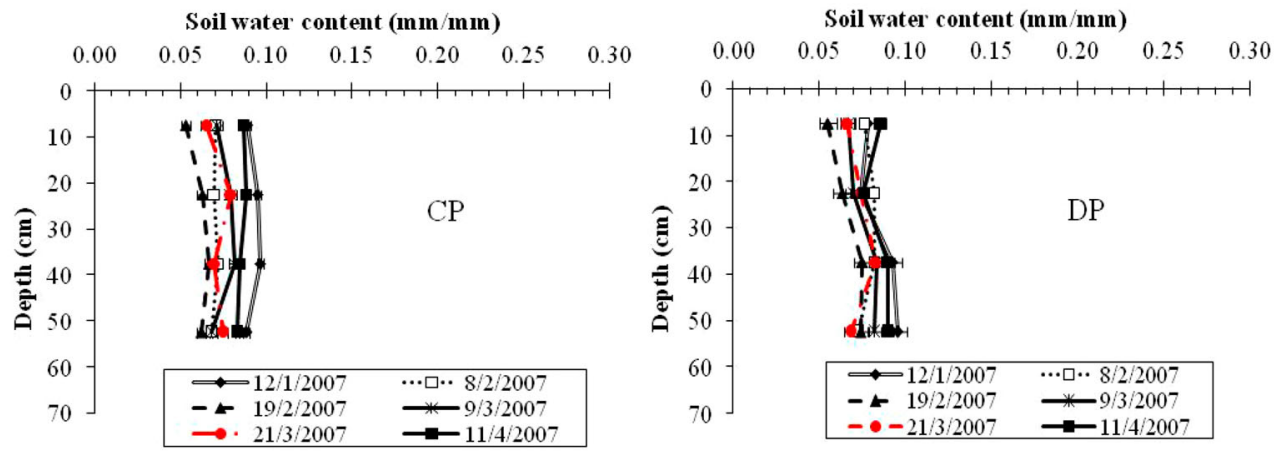

Soil water content ( $(\mathrm{mm} / \mathrm{mm})$
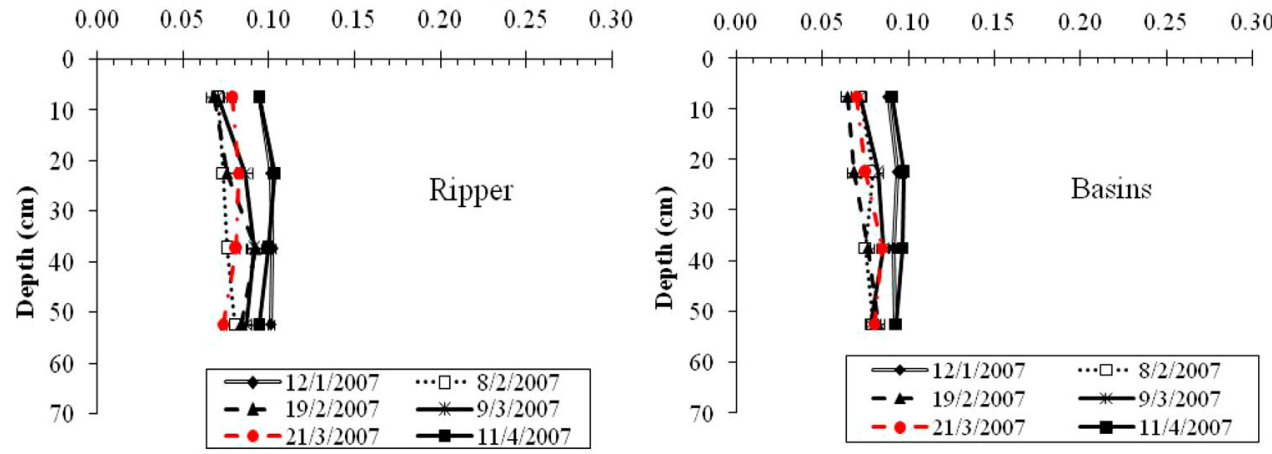

Figure 6. Soil water distribution patterns with soil depth in four tillage methods tested in Insiza district (NR 4 ) during the $2006 / 2007$ season. Horizontal bars represent standard error $(n=6)$.
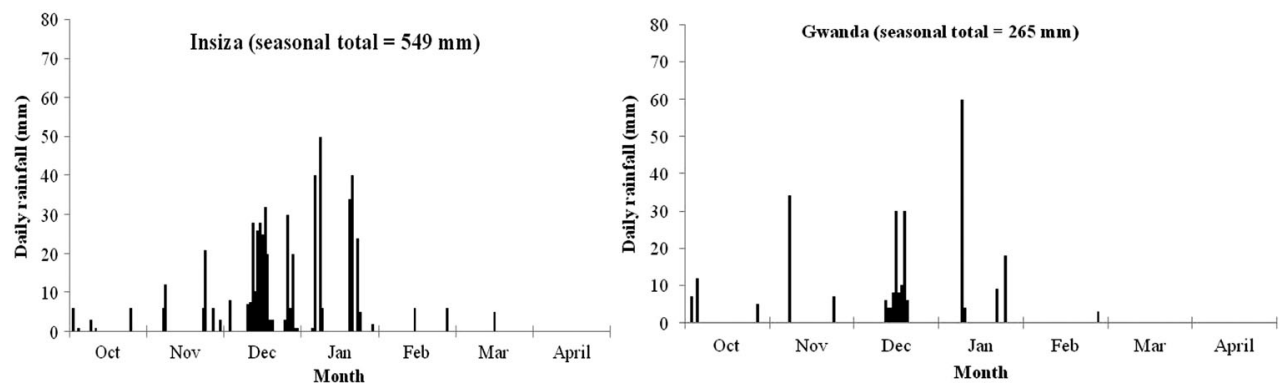

Figure 7. Daily rainfall recorded at some of the experimental sites in Insiza (NR 4) and Gwanda (NR 5) districts during the 2007/2008 cropping season.

varieties (Belfield \& Brown, 2008). The total rainfall recorded at each farm in Insiza was similar to the 74-year average rainfall for Insiza district (Mupangwa et al., 2011). However, farms in Gwanda recorded total rainfall of less than $376 \mathrm{~mm}$, which is the 50 -year average rainfall for Gwanda (Mupangwa et al., 2011). Rainfall was unevenly distributed and below the in-crop requirement for maize in 2006/2007 and 2007/2008 seasons. Dry spells observed during the 2006/2007 growing season are a common characteristic of southern Zimbabwe and have been reported in some years in other parts of southern Africa (Cooper et al., 2008; Tadross, Hewitson, \& Usman, 2005; Usman \& Reason, 2004). The dry spells ranging from 42 days in Insiza to 55 days in Gwanda led to significant maize yield reductions and complete crop failure at most 

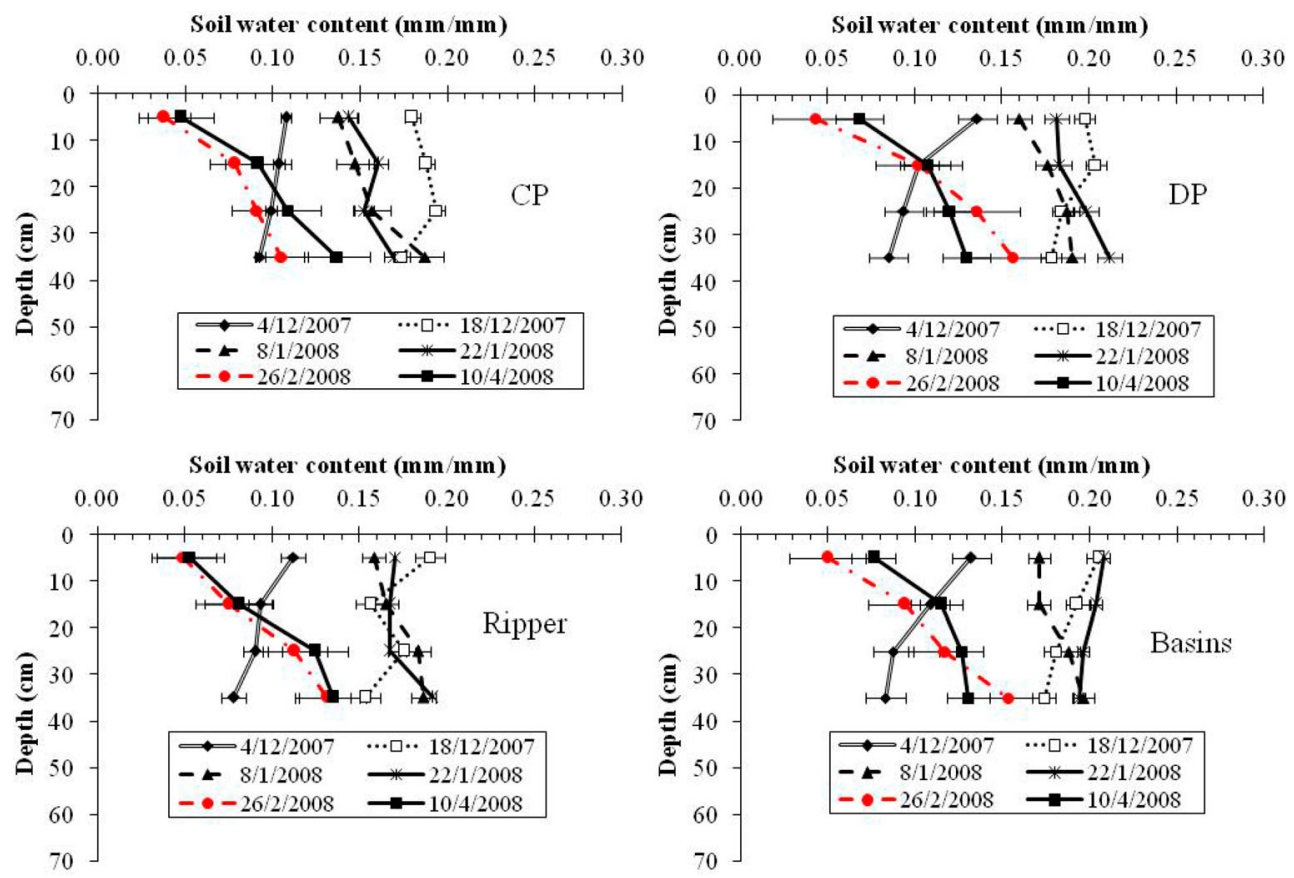

Figure 8. Soil water distribution patterns with soil depth in four tillage methods tested in Gwanda district (NR 5) during the 2007/2008 season. Horizontal bars represent standard error $(n=9)$.

of the farms in the 2006/2007 season. The dry spells occurred 35-85 days after planting maize and this coincided with flowering and grain filling stages of the short seasoned maize variety used in the study. The large variation in daily rainfall distribution observed in 2006/2007 and 2007/2008 growing seasons is common in the Mzingwane catchment and has been reported in other studies (Chibulu, 2007; Love, Uhlenbrook, Twomlow, \& van der Zaag, 2008).

\section{Soil water dynamics under different tillage methods}

Generally, soil water content was higher in the December-January period compared with the second half of growing seasons, and soil water penetrated deeper into the profiles of basin and ripper treatments in a season with above average rainfall. The grid of $0.9 \mathrm{~m} \times 0.6 \mathrm{~m}$ spaced basins and furrows created by ripping created more surface depressions compared with conventionally ploughed treatments resulting in superior rainwater capture and better infiltration. Guzha (2004) observed that the higher the surface roughness, the greater the potential for surface depression water storage, and surface run-off water losses from the cropping field are substantially reduced. As cropping seasons progressed, the basin structure did not collapse completely and this allowed continued capturing of rainwater up to the last rainfall events experienced in some seasons. However, furrows created by ripping filled up with soil much faster compared with the basins and subsequently rainwater capturing decreased with time in the ripper tillage method. No further evidence of deep water penetration was visible especially in the second half of the cropping season. In seasons with early cessation of rainfall (illustrated by 2007/2008), soil profiles in DP and basin treatments dried off slower than those in other treatments and this could offer an opportunity for crops to reach maturity under the two tillage systems. 

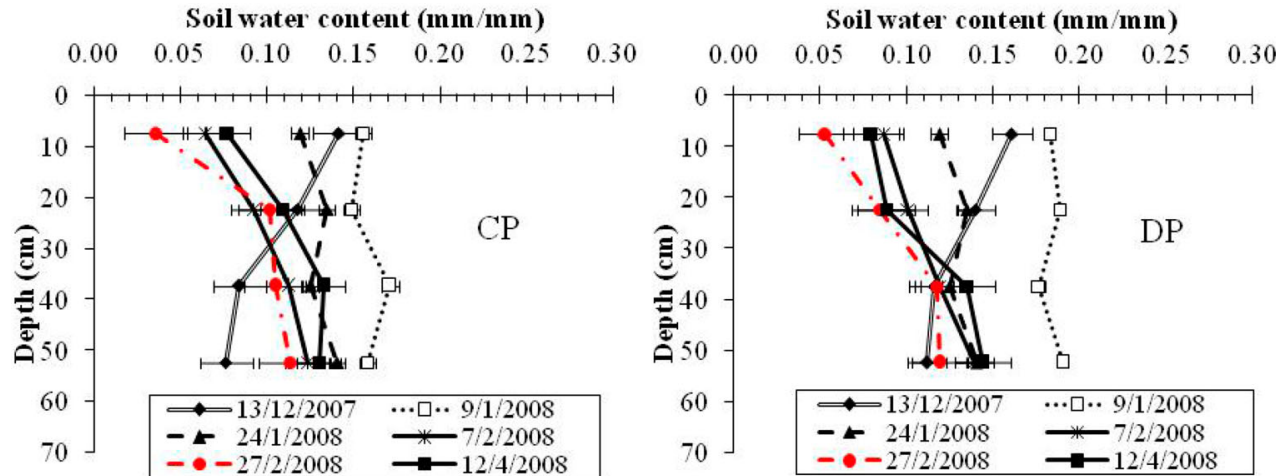

Soil water content $(\mathrm{mm} / \mathrm{mm})$
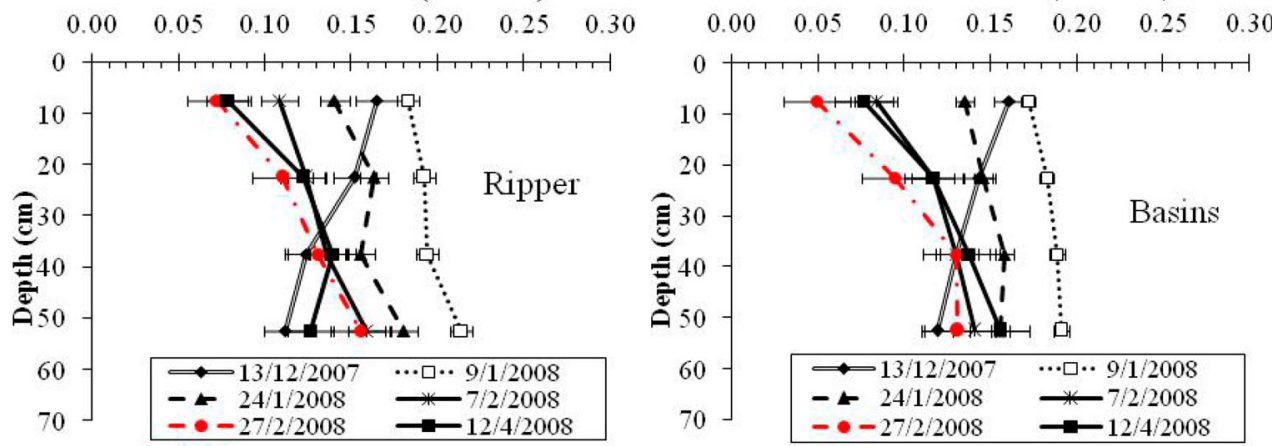

Figure 9. Soil water distribution patterns with soil depth in four tillage methods tested in Insiza district (NR 4 ) during the $2007 / 2008$ season. Horizontal bars represent standard error $(n=9)$.

Table 2. Maize responses to four tillage methods (CP, DP, ripper and basin) and nitrogen fertilizer (0 and $10 \mathrm{~kg} \mathrm{~N} \mathrm{ha}^{-1}$ ) in the 2005/2006 season, Insiza and Gwanda districts.

\begin{tabular}{lcc}
\hline Treatment & Grain yield $\left(\mathrm{kg} \mathrm{ha}^{-1}\right)$ & RWUE $\left(\mathrm{kg} \mathrm{ha}^{-1} \mathrm{~mm}^{-1}\right)$ \\
\hline $\mathrm{N}\left(\mathrm{kg} \mathrm{ha}^{-1}\right)$ & $1247^{\mathrm{b}}$ & $10^{\mathrm{b}}$ \\
0 & $1423^{\mathrm{a}}$ & $12^{\mathrm{a}}$ \\
10 & 0.049 & 0.0015 \\
$P$-value & $1324^{\mathrm{a}}$ & $11^{\mathrm{a}}$ \\
Tillage method & $1510^{\mathrm{a}}$ & $12^{\mathrm{a}}$ \\
$\mathrm{CP}$ & $1157^{\mathrm{a}}$ & $10^{\mathrm{a}}$ \\
$\mathrm{DP}$ & $1349^{\mathrm{a}}$ & $11^{\mathrm{a}}$ \\
Ripper & 0.710 & 0.506 \\
Basins & 0.710 \\
$P$-value &
\end{tabular}

Note: Means in a column followed by the same letter under each treatment are not significantly different at $P=.05$.

Soil water distribution patterns in the ploughed treatments (CP and DP) were comparable with basins and ripper treatments, especially in the first half of cropping seasons. The rainwater capturing ability of CP and DP tillage treatments decreased as the growing season progressed. This initial high soil water content under ploughed treatments can be attributed to increased porosity of the soil following loosening and the short-lived surface depressions created during tillage 
Table 3. Maize responses to four tillage methods (CP, DP, ripper and basin) and nitrogen fertilizer $(0,10$ and $20 \mathrm{kgNha}^{-1}$ ) in the 2006/2007 season, Insiza and Gwanda districts.

\begin{tabular}{lcc}
\hline Treatment & Grain yield $\left(\mathrm{kg} \mathrm{ha}^{-1}\right)$ & RWUE $\left(\mathrm{kg} \mathrm{ha}^{-1} \mathrm{~mm}^{-1}\right)$ \\
\hline $\mathrm{N}\left(\mathrm{kg} \mathrm{ha}^{-1}\right)$ & $282^{\mathrm{b}}$ & $2.4^{\mathrm{c}}$ \\
0 & $413^{\mathrm{ab}}$ & $3.4^{\mathrm{b}}$ \\
10 & $554^{\mathrm{a}}$ & $4.4^{\mathrm{a}}$ \\
20 & 0.0226 & 0.0016 \\
$P$-value & & \\
Tillage method & $304^{\mathrm{a}}$ & $2.5^{\mathrm{a}}$ \\
$\mathrm{CP}$ & $593^{\mathrm{a}}$ & $4.0^{\mathrm{a}}$ \\
DP & $349^{\mathrm{a}}$ & $3.7^{\mathrm{a}}$ \\
Ripper & $418^{\mathrm{a}}$ & $3.4^{\mathrm{a}}$ \\
Basins & 0.084 & 0.185 \\
$P$-value & & \\
\hline
\end{tabular}

Note: Means in a column followed by the same letter under each treatment are not significantly different at $P=.05$.

Table 4. Maize responses to four tillage methods (CP, DP, ripper and basin) and nitrogen fertilizer $(0,10$ and $20 \mathrm{kgNha}^{-1}$ ) in the 2007/2008 season, Insiza and Gwanda districts.

\begin{tabular}{lcc}
\hline Treatment & Grain yield $\left(\mathrm{kg} \mathrm{ha}^{-1}\right)$ & RWUE $\left(\mathrm{kg} \mathrm{ha}^{-1} \mathrm{~mm}^{-1}\right)$ \\
\hline $\mathrm{N}\left(\mathrm{kg} \mathrm{ha}^{-1}\right)$ & & \\
0 & $432^{\mathrm{b}}$ & $3.8^{\mathrm{c}}$ \\
10 & $604^{\mathrm{a}}$ & $5.2^{\mathrm{b}}$ \\
20 & $734^{\mathrm{a}}$ & $6.1^{\mathrm{a}}$ \\
$P$-value & 0.005 & $<0.001$ \\
Tillage & & \\
$\mathrm{CP}$ & $495^{\mathrm{a}}$ & $4.2^{\mathrm{a}}$ \\
$\mathrm{DP}$ & $732^{\mathrm{a}}$ & $5.9^{\mathrm{a}}$ \\
Ripper & $456^{\mathrm{a}}$ & $4.9^{\mathrm{a}}$ \\
Basins & $675^{\mathrm{a}}$ & $5.1^{\mathrm{a}}$ \\
$P$-value & 0.230 & 0.245 \\
\hline
\end{tabular}

Note: Means in a column followed by the same letter under each treatment are not significantly different at $P=.05$.

operations (Bruneau \& Twomlow, 1998). Initially, conventional ploughing reduces bulk density, increases porosity and infiltration capacity of the surface soil layer (Mupangwa, Twomlow, \& Walker, 2013; Sasal, Andriulo, \& Taboada, 2006). However, as the season progresses, compaction begins in the surface soil layer, resulting in a reduction in soil porosity. Consequently, infiltration capacity of the surface soil layer decreases as a result of reduced pore space (Shinde, Magar, \& Kale, 1982). In the 2006/2007 season, daily rainfall was low $\left(<20 \mathrm{~mm} \mathrm{day}^{-1}\right)$, poorly distributed and dominated by light showers, which could not meaningfully recharge the soil profile. Rainfall events of $>20 \mathrm{~mm} \mathrm{day}^{-1}$ were sparsely spaced, resulting in low soil water content observed during the seasons. Soil moisture in the top $0-10 \mathrm{~cm}$ soil layer is quickly lost through soil evaporation in semi-arid areas where daily evaporation can be as high as $8 \mathrm{~mm}$ (Woltering, 2005).

\section{Maize grain yield and RWUE}

Seasonal rainfall patterns had a significant influence on maize yield and RWUE during the three years of experimentation. In the $2005 / 2006$ season, soil water was not a limiting factor to maize 
crop growth and the effect of tillage methods on rainwater retention was eliminated because of the above average rainfall. Soil water availability was a major constraint for maize growth in 2006/ 2007 and 2007/2008 because of low and poorly distributed rainfall received during the two seasons. The 2006/2007 season had the lowest grain yield and RWUE after experiencing 42-55 day long dry spells in Insiza and Gwanda. The dry spells occurred during flowering and silking stages of the hybrid maize variety (SC 403) grown in the experiment. Maize is more sensitive to water stress at its flowering and grain filling stages compared with other growth stages (NeSmith \& Ritchie, 1992; Otegui, Andrade, \& Suero, 1995; Otegui \& Bonhomme, 1998; Pandey, Maranville, \& Chetima, 2000). Soil water stress during flowering and ear formation stages of maize significantly reduce grain yield (Cakir, 2004) and this could have caused the low yields and RWUE achieved in 2006/2007 and 2007/2008 seasons. Effective grain filling in maize is also highly dependent on the availability of assimilates and these are significantly influenced by soil water availability (Maddonni, Otegui, \& Bonhomme, 1998). Otegui et al. (1995) also report that soil water stress during maize flowering and silking stages reduces yield because these are the growth stages at which kernel number on each maize cob is defined.

Addition of $\mathrm{N}$ fertilizer increased maize yield regardless of the rainfall amount and distribution during growing seasons. Nitrogen is one of the major yield limiting nutrients in Zimbabwean soils (Grant, 1981; Mapfumo \& Giller, 2001) and positive maize yield responses to $\mathrm{N}$ in our study are consistent with observations made in previous studies from semi-arid southern Zimbabwe (Ncube, Dimes, et al., 2007, Ncube, Twomlow, et al., 2007; Twomlow, Urolov, et al., 2008). Nitrogen fertilizer use in semi-arid southern Zimbabwe showed significant maize yield gains following the application of $10 \mathrm{~kg} \mathrm{~N}^{-1}$ on smallholder farms (Twomlow, Urolov, et al., 2008). Studies by Ncube, Dimes, et al. (2007) revealed significant maize yield gains through combining 3-6 $\mathrm{tha}^{-1}$ of cattle manure with $10 \mathrm{~kg} \mathrm{~N} \mathrm{ha}^{-1}$. Maize yield responses to $\mathrm{N}$ fertilizer were small in the wet 2005/2006 season and this can be attributed to the smaller quantity of $10 \mathrm{~kg} \mathrm{~N} \mathrm{ha}^{-1}$ applied in a growing season that received above average and well-distributed rainfall. Some of the applied N could have been lost through leaching during a growing season with above average rainfall. Mapfumo and Giller (2001) report that leaching is a common pathway of $\mathrm{N}$ loss on light textured soils. In the 2005/2006 season, poor maize response to favourable soil water conditions could have been caused by the inherent low fertility of the soils at all experimental sites. Soils at all experimental sites were acidic and below the recommended lowermost $\mathrm{pH}$ level for maize growth. Maize grows well at soil $\mathrm{pH}$ of 5.5-7.8 and values below this range can cause nutrient deficiencies (Lafitte, 1994). There could have been deficiencies of other nutrients in addition to $\mathrm{N}$ and this reduced grain production despite the favourable soil moisture conditions in the 2005/2006 season. However, the importance of $\mathrm{N}$ in improving maize yields was confirmed by the linear and quadratic relationships recorded in 2006/2007 and 2007/2008 seasons. Nitrogen increases grain production until a peak is reached and other factors become limiting, and this was illustrated by the quadratic relationship in the $2007 / 2008$ season.

\section{Conclusions and recommendations}

This study demonstrated that under semi-arid conditions of southern Zimbabwe the effect of CP, DP, ripper and basin tillage methods on soil water distribution in the profile depended on a seasonal rainfall pattern. Basins and tine ripping promote deeper water penetration and better soil profile recharge in some seasons compared with CP and DP tillage treatments. Conventionally, ploughed treatments capture rainwater at the beginning of season but lose that capability as the season progresses. Double ploughing has the potential of capturing and storing moisture from the early rains as effective as basins and ripper tillage methods, but its rainwater-harvesting 
ability is lost as the growing season progresses. Timing of the first ploughing in the DP system could be critical so that the early spring rains are captured and stored in the soil profile. In seasons with above and below average rainfall, soil water distribution patterns in profiles under CP, DP, ripper and basins can be similar under semi-arid smallholder conditions. In seasons with early cessation of rain, soil water became a limiting factor for maize growth in all tillage methods. There is therefore scope for farmers to explore more in-field and inter-field techniques for improving rainwater capture and soil water storage in cropping fields.

The CP and DP methods gave crop yields and RWUE similar to those for ripper and basins treatments, regardless of the seasonal rainfall pattern. Nitrogen increases maize yield and RWUE regardless of the tillage method used under semi-arid smallholder conditions. In semi-arid smallholder agro-ecosystems, $\mathrm{N}$ fertilizer improves maize yields in all tillage systems regardless of the seasonal rainfall pattern. The study highlights the fact that tillage alone cannot adequately address soil water constraints on farmers' fields under semi-arid conditions. The results suggest that soil water management interventions/practices and $\mathrm{N}$ fertilizer are required concurrently in semi-arid smallholder cropping systems of southern Zimbabwe. In addition to inorganic fertilizer as a source of $\mathrm{N}$, smallholder farmers in semi-arid areas could also explore the incorporation of drought tolerant leguminous species that can serve dual purposes of soil improvement and livestock feed supply. There is also scope for more soil-fertility research on other nutrients in addition to $\mathrm{N}$ on smallholder farms in semi-arid areas of southern Africa.

\section{Acknowledgements}

We are grateful to farmers in Insiza and Gwanda, and the ICRISAT field staff (Beckimpilo Ncube and Thulani Ndlovu) for assisting in experimental management and data collection.

\section{Disclosure statement}

No potential conflict of interest was reported by the authors.

\section{Funding}

The authors thank WaterNet for funding this research through the Challenge Program Project 17 "Integrated Water Resource Management for Improved Rural Livelihoods: Managing risk, mitigating drought and improving water productivity in the water scarce Limpopo Basin", funded through the CGIAR Challenge Program on Water and Food. Additional funding received from ICRISAT is gratefully acknowledged.

\section{References}

Alvarez-Mozos, J., Angel Campo, M., Gimenez, R., Casali, J., \& Leibar, U. (2011). Implications of scale, slope, tillage operation and direction in the estimation of surface depression storage. Soil Tillage Research, 111, 142-153.

Anderson, I. P., Brinn, P. J., Moyo, M., \& Nyamwanza, B. (1993). Physical resource inventory of communal lands of Zimbabwe (p. 60). London: Natural Resources Institute Bulletin.

Anderson, J. M., \& Ingram, J. S. I. (1997). Tropical soil biology and fertility. A handbook of methods (2nd ed.). Wallingford: C.A.B. International.

Belfield, S., \& Brown, C. (2008). Field crop manual: Maize. A guide for Upland production in Cambodia. New South Wales: NSW Department of Primary Industries.

Bruneau, P. M. C., \& Twomlow, S. J. (1998). Hydrological and physical responses of a semi-arid sandy soil to tillage. Agricultural Engineering Research, 72, 385-391.

Cakir, R. (2004). Effect of water stress at different development stages on vegetative and reproductive growth of corn. Field Crops Research, 89, 1-16.

Chibulu, B. (2007). Effect of rainfall variability on crop yield under semi-arid conditions at sub-catchment level (M.Sc. thesis). Department of Civil Engineering, University of Zimbabwe, Harare. 
Cobo, J. G., Dercon, G., \& Cadisch, G. (2010). Nutrient balances in African land use systems across different spatial scales: A review of approaches, challenges and progress. Agriculture, Ecosystems and Environment, 136, 1-15.

Cooper, P. J. M., Dimes, J., Rao, K. P. C., Shapiro, B., Shiferaw, B., \& Twomlow, S. (2008). Coping better with current climatic variability in the rain-fed farming systems of sub-Saharan Africa: An essential first step in adapting to future climate change? Agriculture, Ecosystem and Environment, 126, 24-35.

Debaeke, P., \& Aboudrare, A. (2004). Adaptation of crop management to water limited environments. European Journal of Agronomy, 21, 433-446.

De Barros, I., Gaiser, T., Lange, F., \& Romheld, V. (2007). Mineral nutrition and water use patterns of a maize/ cowpea intercrop on a highly acidic soil of the tropic semi-arid. Field Crops Research, 101, 26-36.

Dimes, J., Muza, L., Malunga, G., \& Snapp, S. (2004). Trade-offs between investments in nitrogen and weeding: On-farm experimentation and simulation analysis in Malawi and Zimbabwe. In D. K. Friesen \& A. F. E. Palmer (Eds.), Integrated approaches to higher maize production in the New Millennium: Proceedings of the Eastern and Southern Africa Regional maize conference, February 2001, Nairobi, Kenya (pp. 452-456). Mexico: CIMMYT Maize Program.

Dryland Farming Research Scheme (DLFRS) Phase III. (1985). Digest of research findings (Final report, 6). London: Overseas Development Administration.

FAO. (2004). Drought impact mitigation and prevention in the Limpopo River Basin. Land and Water Discussion Paper 4. Rome: Food and Agriculture Organisation of the United Nations.

FAO. (2006). Fertilizer use by crop in Zimbabwe. Land and Plant Nutrition Services. Land and Water Development Division. Rome: Food and Agriculture Organisation of the United Nations.

Graef, F., \& Haigis, J. (2001). Spatial and temporal rainfall variability in the Sahel and its effects on farmers' management strategies. Arid Environments, 48, 1-11.

Grant, P., Meikle, G. J., \& Mills, W. R. (1979). A comparison of plough types and depths of annual ploughing for maize monoculture with varied manuring. Rhodesian Journal of Agricultural Research, 17, 99-123.

Grant, P. M. (1981). The fertilization of sandy soils in peasant agriculture. Zimbabwe Agriculture Journal, $78,169-175$.

Guzha, A. C. (2004). Effect of tillage on soil micro relief, surface depression storage and soil water storage. Soil Tillage Research, 76, 105-114.

Kolawole, O. D. (2013). Soils, science and the politics of knowledge: How African smallholder farmers are framed and situated in the global debate on integrated soil fertility management. Land Use Policy, 30, $470-484$.

Lafitte, H. R. (1994). Identifying production problems in tropical maize: A field guide. Mexico: CIMMYT.

Love, D., Uhlenbrook, S., Twomlow, S., \& van der Zaag, P. (2008). Changing rainfall and discharge patterns in the northern Limpopo Basin, Zimbabwe. Water SA, 36(3), 335-350.

Maddonni, G. A., Otegui, M. E., \& Bonhomme, R. (1998). Grain yield components in maize. II. Post silking growth and kernel weight. Field Crops Research, 56, 257-264.

Mapfumo, P., \& Giller, K. E. (2001). Soil fertility management strategies and practices by smallholder farmers in semi-arid areas of Zimbabwe. Bulawayo: International Crops Research Institute for the Semi Arid Tropics (ICRISAT) and Food and Agriculture Organization of the United Nations (FAO).

Motsi, K. E., Chuma, E., \& Mukamuri, B. B. (2004). Rainwater harvesting for sustainable agriculture in communal lands of Zimbabwe. Physics and Chemistry of the Earth, 29, 1069-1073.

Mugabe, F. (2004). Evaluation of the benefits of infiltration pits on soil moisture in semi-arid Zimbabwe. Journal of Agronomy, 3, 188-190.

Mupangwa, W. (2009). Water and nitrogen management for risk mitigation in smallholder cropping systems (Unpublished Ph.D. thesis). University of the Free State, South Africa.

Mupangwa, W., \& Jewitt, G. (2011). Simulating the impact of no-till system on field water fluxes and maize productivity under semi-arid conditions. Physics and Chemistry of the Earth, 36, 1004-1011.

Mupangwa, W., Love, D., \& Twomlow, S. J. (2006). Soil-water conservation and rainwater harvesting strategies in the semi-arid Mzingwane Catchment, Limpopo Basin, Zimbabwe. Physics and Chemistry of the Earth, 31, 893-900.

Mupangwa, W., Twomlow, S., \& Walker, S. (2008). The influence of conservation tillage methods on soil water regimes in semi-arid southern Zimbabwe. Physics and Chemistry of the Earth, 33, 762-767.

Mupangwa, W., Twomlow, S., \& Walker, S. (2012a). Reduced tillage, mulching and rotational effects on maize (Zea mays L.), cowpea (Vigna unguiculata (Walp) L.) and sorghum (Sorghum bicolor L. (Moench)) yields under semi-arid conditions. Field Crops Research, 132, 139-148. 
Mupangwa, W., Twomlow, S., \& Walker, S. (2012b). Dead level contours and infiltration pits for risk mitigation in smallholder cropping systems of southern Zimbabwe. Physics and Chemistry of the Earth, 47$48,166-172$.

Mupangwa, W., Twomlow, S., \& Walker, S. (2013). Cumulative effects of reduced tillage and mulching on soil properties under semi-arid conditions. Arid Environments, 91, 45-52.

Mupangwa, W., Walker, S., \& Twomlow, S. (2011). Start, end and dry spells of the growing season in semiarid southern Zimbabwe. Arid Environments, 75, 1097-1104.

Ncube, B., Dimes, J. P., Twomlow, S., Mupangwa, W., \& Giller, K. E. (2007). Raising the productivity of smallholder farms under semi-arid conditions by use of small doses of manure and nitrogen: A case of participatory research. Nutrient Cycling in Agroecosystems, 77, 53-67.

Ncube, B., Dimes, J. P., van Wijk, M. T., Twomlow, S. J., \& Giller, K. E. (2009). Productivity and residual benefits of grain legumes to sorghum under semi-arid conditions in south-western Zimbabwe: Unravelling the effects of water and nitrogen using simulation modelling. Field Crops Research, 110, $173-184$.

Ncube, B., Twomlow, S., van Wijk, M. T., Dimes, J. P., \& Giller, K. E. (2007). Productivity and residual benefits of grain legumes to sorghum under semi-arid conditions in south-western Zimbabwe. Plant and Soil, 299, 1-15.

NeSmith, D. S., \& Ritchie, J. T. (1992). Effects of soil water deficits during tassel emergence on development and yield component of maize (Zea mays L.). Field Crops Research, 28, 251-256.

Nyagumbo, I. (2002). The effect of three tillage systems on seasonal water budgets and drainage of two Zimbabwean soils under maize (Ph.D. thesis). Department of Soil Science and Agricultural Engineering, University of Zimbabwe.

Nyakatawa, E. Z., Brown, M., \& Maringa, D. (1996). Maize and sorghum yields under tied ridges of fertilised sandy soils in semi-arid south-east lowveld of Zimbabwe. African Crop Science, 4, 197-206.

Nyamapfene, K. (1991). Soils of Zimbabwe. Harare: NeHanda.

Otegui, M. E., Andrade, F. H., \& Suero, E. E. (1995). Growth, water use and kernel abortion of maize subjected to drought at silking. Field Crops Research, 40, 87-94.

Otegui, M. E., \& Bonhomme, R. (1998). Grain yields components in maize. I. Ear growth and kernel set. Field Crops Research, 56, 247-256.

Pandey, R. K., Maranville, J. W., \& Chetima, M. M. (2000). Deficit irrigation and nitrogen effects on maize in a Sahelian environment. II. Shoot growth, nitrogen uptake and water extraction. Agriculture Water Management, 46, 15-27.

Sasal, M. C., Andriulo, A. E., \& Taboada, M. A. (2006). Soil porosity characteristics and water movement under zero tillage in silty soils in Argentinean Pampas. Soil Tillage Research, 87, 9-18.

Shinde, S. S., Magar, S. S., \& Kale, S. P. (1982). Effect of soil physical conditions and initial soil moisture content on infiltration into black soil. Indian Society of Soil Science, 30, 441-446.

Statistix (2008). Statistix 9: Analytical Software. Tallahassee. www.statistix.com.

Tadross, M., Hewitson, B. C., \& Usman, M. T. (2005). The inter-annual variability of onset of the maize growing season over South Africa and Zimbabwe. Journal of Climate, 18, 3356-3372.

Twomlow, S., Rohrbach, D., Dimes, J., Rusike, J., Mupangwa, W., Ncube, B., ... Maphosa, P. (2008). Micro-dosing as a pathway to Africa's Green Revolution: Evidence from broad-scale on-farm trials. Nutrient Cycling in Agroecosystem, 88, 3-15.

Twomlow, S. J., \& Bruneau, P. M. (2000). The influence of tillage on semi-arid soil-water regimes in Zimbabwe. Geoderma, 95, 33-51.

Twomlow, S. J., Hove, L., Mupangwa, W., Masikati, P., \& Mashingaidze, N. (2009). Precision conservation agriculture for vulnerable farmers in low potential zones. In E. Humphreys \& R. S. Bayot (Eds.), Increasing the productivity and sustainability of rainfed cropping systems for poor smallholder farmers: Proceedings of the CGIAR Challenge program on Water and Food International Workshop on Rainfed Cropping Systems, Tamale, Ghana (pp. 37-54). Colombo: CGIAR Challenge Program on Water and Food.

Twomlow, S. J., Steyn, J. T., \& du Preez, C. C. (2006). Dryland farming in southern Africa. In G. A. Petersen, W. P. Unger, \& W. A. Payne (Eds.), Dryland Agriculture (2nd ed., pp. 769-836). Madison, WI: Agronomy Monograph No. 23. American Society of Agronomy.

Twomlow, S. J., Urolov, J. C., Oldrieve, B., \& Jenrich, M. (2008). Lessons from the field - Zimbabwe's conservation agriculture taskforce. SAT Agricultural Research, 6, 1-11.

Usman, M. T., \& Reason, C. J. C. (2004). Dry spell frequencies and their variability over southern Africa. Climate Research, 26, 199-211. 
Vogel, H. (1992). Tillage effects on maize yield, rooting depth and soil water content on sandy soils in Zimbabwe. Field Crops Research, 33, 376-384.

Woltering, L. (2005). Estimating the influence of on-farm conservation practices on the water balance: Case of the Mzinyathini catchment in Zimbabwe (M.Sc. thesis). Delft University of Technology, The Netherlands. 